\title{
REVIEW
}

Open Access

\section{AL Amyloidosis}

Estelle Desport ${ }^{1}$, Frank Bridoux ${ }^{1,2}$, Christophe Sirac ${ }^{2}$, Sébastien Delbes ${ }^{1}$, Sébastien Bender ${ }^{2}$, Béatrice Fernandez $^{3}$, Nathalie Quellard ${ }^{3}$, Corinne Lacombe ${ }^{1}$, Jean-Michel Goujon ${ }^{3}$, David Lavergne ${ }^{5}$, Julie Abraham ${ }^{5}$, Guy Touchard ${ }^{1}$, Jean-Paul Fermand ${ }^{4}$ and Arnaud Jaccard ${ }^{5^{*}}$ Centre national de référence pour l'amylose AL et les autres maladies par dépôts d'immunoglobulines monoclonales

\begin{abstract}
Definition of the disease: AL amyloidosis results from extra-cellular deposition of fibril-forming monoclonal immunoglobulin (lg) light chains (LC) (most commonly of lambda isotype) usually secreted by a small plasma cell clone. Most patients have evidence of isolated monoclonal gammopathy or smoldering myeloma, and the occurrence of AL amyloidosis in patients with symptomatic multiple myeloma or other B-cell lymphoproliferative disorders is unusual. The key event in the development of AL amyloidosis is the change in the secondary or tertiary structure of an abnormal monoclonal LC, which results in instable conformation. This conformational change is responsible for abnormal folding of the $L C$, rich in $\beta$ leaves, which assemble into monomers that stack together to form amyloid fibrils.
\end{abstract}

Epidemiology: $\mathrm{AL}$ amyloidosis is the most common type of systemic amyloidois in developed countries with an estimated incidence of 9 cases/million inhabitant/year. The average age of diagnosed patients is 65 years and less than $10 \%$ of patients are under 50 .

Clinical description: The clinical presentation is protean, because of the wide number of tissues or organs that may be affected. The most common presenting symptoms are asthenia and dyspnoea, which are poorly specific and may account for delayed diagnosis. Renal manifestations are the most frequent, affecting two thirds of patients at presentation. They are characterized by heavy proteinuria, with nephrotic syndrome and impaired renal function in half of the patients. Heart involvement, which is present at diagnosis in more than $50 \%$ of patients, leading to restrictive cardiopathy, is the most serious complication and engages prognosis.

Diagnostic methods: The diagnosis relies on pathological examination of an involved site showing Congo red-positive amyloid deposits, with typical apple-green birefringence under polarized light, that stain positive with an anti-LC antibody by immunohistochemistry and/or immunofluorescence. Due to the systemic nature of the disease, non-invasive biopsies such as abdominal fat aspiration should be considered before taking biopsies from involved organs, in order to reduce the risk of bleeding complications.

Differential diagnosis: Systemic AL amyloidosis should be distinguished from other diseases related to deposition of monoclonal LC, and from other forms of systemic amyloidosis. When pathological studies have failed to identify the nature of amyloid deposits, genetic studies should be performed to diagnose hereditary amyloidosis.

(Continued on next page)

\footnotetext{
* Correspondence: arnaud.jaccard@chu-limoges.fr

${ }^{5}$ Service d'Hématologie et de Thérapie Cellulaire, CHU de Limoges, 2, avenue

Martin Luther King, Limoges 87042 Cedex, France

Full list of author information is available at the end of the article
}

\section{Biomed Central}

(c) 2012 Desport et al.; licensee BioMed Central Ltd. This is an Open Access article distributed under the terms of the Creative Commons Attribution License (http://creativecommons.org/licenses/by/2.0), which permits unrestricted use, distribution, and reproduction in any medium, provided the original work is properly cited. 


\begin{abstract}
(Continued from previous page)
Management: Treatment of AL amyloidosis is based on chemotherapy, aimed at controlling the underlying plasma clone that produces amyloidogenic LC. The hematological response should be carefully checked by serial measurements of serum free LC. The association of an alkylating agent with high-dose dexamethasone has proven to be effective in two thirds of patients and is considered as the current reference treatment. New agents used in the treatment of multiple myeloma are under investigation and appear to increase hematological response rates. Symptomatic measures and supportive care is necessary in patients with organ failure. Noticeably, usual treatments for cardiac failure (i.e. calcium inhibitors, $\beta$-blockers, angiotensin converting enzyme inhibitors) are inefficient or even dangerous in patients with amyloid heart disease, that should be managed using diuretics. Amiodarone and pace maker implantation should be considered in patients with rhythm or conduction abnormalities. In selected cases, heart and kidney transplantation may be associated with prolonged patient and graft survival.
\end{abstract}

Prognosis: Survival in AL amyloidosis depends on the spectrum of organ involvement (amyloid heart disease being the main prognosis factor), the severity of individual organs involved and haematological response to treatment.

Keywords: AL amyloidosis, Immunoglobulinic amyloidosis, « Primary » amyloidosis

\section{Definition}

Amyloidosis belongs to the group of protein conformational diseases and results from the ability of certain proteins to adopt an unstable tertiary structure leading to their polymerisation into insoluble amyloid fibrils in the extra-cellular space of various tissues. Twenty-seven proteins have been described as amyloidogenic precursors. Immunoglobulinic amyloidosis, also referred to as $\mathrm{AL}$ or "primary" amyloidosis, in which fibrils are made up of a monoclonal immunoglobulin (Ig) light chain (LC), is the most common and the most severe form of amyloidosis. AL amyloidosis is usually a systemic disease characterized by multiple organ and tissue involvement. Less frequently, it manifests as a local disorder, restricted to a single tissue or organ, related to focal infiltration of a plasma cell clone secreting amyloid-forming LC, that do not progress to multi-system involvement. Therefore, the disease spectrum of AL amyloidosis is broad, ranging from mild symptoms in some patients with localized AL amyloidosis that can be managed with local therapy, to life threatening disorders in those with multiple organ deposition, which require prompt diagnosis and aggressive therapy to preserve survival [1].

\section{Epidemiology of AL amyloidosis}

$\mathrm{AL}$ amyloidosis is considered to be 5 to 10 times less frequent than multiple myeloma, but it represents the most common type of systemic amyloidosis in western countries, with an incidence estimated to be around 9 cases per million inhabitants per year, whereas the frequency of AA amyloidosis has considerably decreased thanks to better treatment of chronic infectious and inflammatory diseases [2]. AL amyloidosis affects men slightly more often than women. The average age of diagnosed patients is 65 years and around $10 \%$ of patients are less than 50 years old.

\section{Clinical characteristics}

\section{Systemic AL amyloidosis}

All organs can be affected in systemic AL amyloidosis, except for central nervous system. The most frequent presenting symptoms are asthenia and dyspnoea, which are poorly specific and may account for delayed diagnosis. Organ involvement in systemic AL amyloidosis is now defined by consensus criteria, which have been updated at the 2010 meeting of the International Society of Amyloidosis in Rome [Table 1] [3-5].

Kidney involvement is the most frequent, found in two thirds of patients at the time of diagnosis. If renal manifestations are absent initially, they seldom appear during follow-up. Characteristic presentation is with heavy proteinuria (composed mainly of albumin, with detectable urine monoclonal Ig LC in most cases), with nephrotic syndrome and decreased glomerular filtration rate in 20 to $45 \%$ of cases [6-8]. Contrasting with Randall-type monoclonal LC deposition disease (LCDD), haematuria and hypertension are uncommon. It is usually considered that increased kidney size is characteristic of $\mathrm{AL}$ amyloid nephropathy, but this is not a constant feature, as shown by echographic studies [8]. The diagnosis of renal amyloidosis relies on the pathological demonstration of renal amyloid and/or, when a kidney biopsy is not available, on histological evidence from another tissue with proteinuria $\geq 0.5 \mathrm{~g} /$ day predominantly composed of albumin $[3,4]$.

Pathological heart involvement is present in up to $90 \%$ of patients, and approximately $50 \%$ present with diastolic heart failure at the time of diagnosis [9]. Amyloid heart disease is a major prognosis factor as it account for approximately $75 \%$ of deaths, due to heart failure or arrhythmia [10,11]. Amyloid deposition within the myocardium results in thickening of ventricular and atrial walls leading to restrictive cardiopathy responsible for progressively increasing asthenia, dyspnoea and lower 


\begin{tabular}{|c|c|}
\hline Involved organ or tissue & Criteria \\
\hline Kidney & $\begin{array}{l}\text { 24-hr urine protein }>=0.5 \mathrm{~g} / \text { day, } \\
\text { predominantly albumin }\end{array}$ \\
\hline Heart & $\begin{array}{l}\text { NT-proBNP }>332 \mathrm{ng} / \text { (in the absence } \\
\text { of renal failure or atrial fibrillation) or } \\
\text { mean wall thickness in diastole by } \\
\text { echography }>12 \mathrm{~mm} \text {, no other } \\
\text { cardiac cause }\end{array}$ \\
\hline Liver & $\begin{array}{l}\text { Total liver span }>15 \mathrm{~cm} \text { in the absence } \\
\text { of heart failure, or alkaline } \\
\text { phosphatase }>1.5 \text { times } \\
\text { institutional upper limit of normal }\end{array}$ \\
\hline \multirow[t]{2}{*}{ Nerve } & $\begin{array}{l}\text { Peripheral: Symmetric lower extremity } \\
\text { sensorimotor peripheral neuropathy }\end{array}$ \\
\hline & $\begin{array}{l}\text { Autonomic: gastric-emptying disorder, } \\
\text { pseudo-obstruction,voiding dysfunction } \\
\text { not related to direct organ infiltration. }\end{array}$ \\
\hline Gastro-intestinal tract & Direct biopsy verification with symptoms \\
\hline \multirow[t]{2}{*}{ Lung } & Direct biopsy verification with symptoms \\
\hline & Interstitial radiographic pattern \\
\hline Soft tissues & $\begin{array}{l}\text { Tongue enlargement, arthropathy, } \\
\text { claudication (presumed vascular } \\
\text { amyloid), skin lesions, myopathy } \\
\text { (by biopsy or pseudohypertrophy), } \\
\text { lymph node (may be localized), } \\
\text { carpal tunnel syndrome }\end{array}$ \\
\hline
\end{tabular}

From Gertz et al. ( 3,4$)$ with permission.

limb oedema. Infiltration of the cardiac muscle may also induce conduction disorders and ventricular or supraventricular arrhythmias. Amyloid deposits sometimes affect coronary arteries, and may manifest with symptoms of coronary heart disease or myocardial infarction [10-12].

Peripheral nerve involvement, present in $20 \%$ of patients with AL amyloidosis, is characterized by painful, slowly progressing sensorimotor peripheral polyneuropathy, similar to diabetic neuropathy. Carpal tunnel syndrome is also common. Autonomic neuropathy, isolated or associated with symptoms of peripheral neuropathy, is a particularly severe complication that manifests with gastroparesia, diarrhoea or constipation, impotence and is often responsible for severe postural hypotension. The latter can be extremely disabling, leading to prolonged decubitus and greatly impacts on survival.

Often asymptomatic, gastro-intestinal tract involvement is common, as shown in over $80 \%$ of biopsies samples taken from the rectum or stomach. Usual symptoms include impaired intestinal transit (possibly enhanced by autonomic neuropathy) or occult bleeding. More severe complications may occur, such as malabsorption, perforations, haemorrhages or acute intestinal obstruction.

Macroglossia, highly suggestive of AL amyloidosis, is only found in $15 \%$ of cases. When severe, it may be responsible for feeding problems and/or obstruction of the upper airways (Figure 1A).

Hepatic manifestations, observed in $30 \%$ of patients, usually consist of liver enlargement, accompanied by isolated increased serum alkaline phosphatase levels, without evidence of hepatic failure. Liver disease is easily demonstrated by scintigraphy with ${ }^{123}$ I -labelled serum amyloid $\mathrm{P}$ component $\left({ }^{123}\right.$ I-SAP), which is currently not available in all countries. Transient elastography (Fibroscan), a noninvasive method to evaluate hepatic stiffness should help diagnose liver amyloidosis [13]. In rare cases, a severe form of cholestatic hepatitis may occur, usually rapidly fatal in the absence of efficient treatment.

Spleen involvement is nearly constant and usually asymptomatic. In patients with massive deposits, signs of hyposplenism (Howell-Joly bodies) may be detected on blood smears often with thrombocytemia. Spontaneous spleen rupture has been described in some patients.

Lung disease is mainly characterized by interstitial amyloid infiltration (Figure 1E) whose clinical expression depends on the diffusion and localization of deposits. Rapidly progressive respiratory deficiency may result from bronchiolar and alveolar involvement. It appears to be more frequent in patients with serum IgM paraprotein [14]. Isolated lung nodules are usually related to localized AL amyloidosis.

A wide range of skin lesions have been described, from the characteristic periorbital haematoma, to various papules, nodules, patches or, exceptionally, blisters, mainly localized on the face and trunk (Figure 1B).

Joint symptoms manifest as progressive bilateral and symmetrical polyarthropathy involving fingers, wrists, shoulders and knees. Amyloid deposits may infiltrate tendon sheaths resulting in the classical "shoulder pad" sign. When they invade muscle belts they may cause muscular enlargement, resulting in a "pseudo-athletic" appearance (often associated with amyloid cardiopathy) (Figure 1C).

The infiltration of the exocrine glands may be responsible for sicca syndrome and thyroid or adrenal deficiencies. Finally, AL amyloidosis is associated with a risk of potentially serious haemorrhagic complications, resulting from vascular infiltration, sometimes combined with deficit in coagulation factors (mainly in factor X, less commonly in factors V or IX) or with increased fibrinolysis [2,6,7,15-17].

\section{Localized AL amyloidosis}

In some patients, AL amyloidosis is a localized phenomenon, related to deposition of monoclonal LC close to their synthesis by a focal plasma cell clone. Most patients do not have evidence of monoclonal gammopathy. The bladder, urinary tract, tracheobronchial system, lungs, larynx, ocular globe and skin are the main organs 


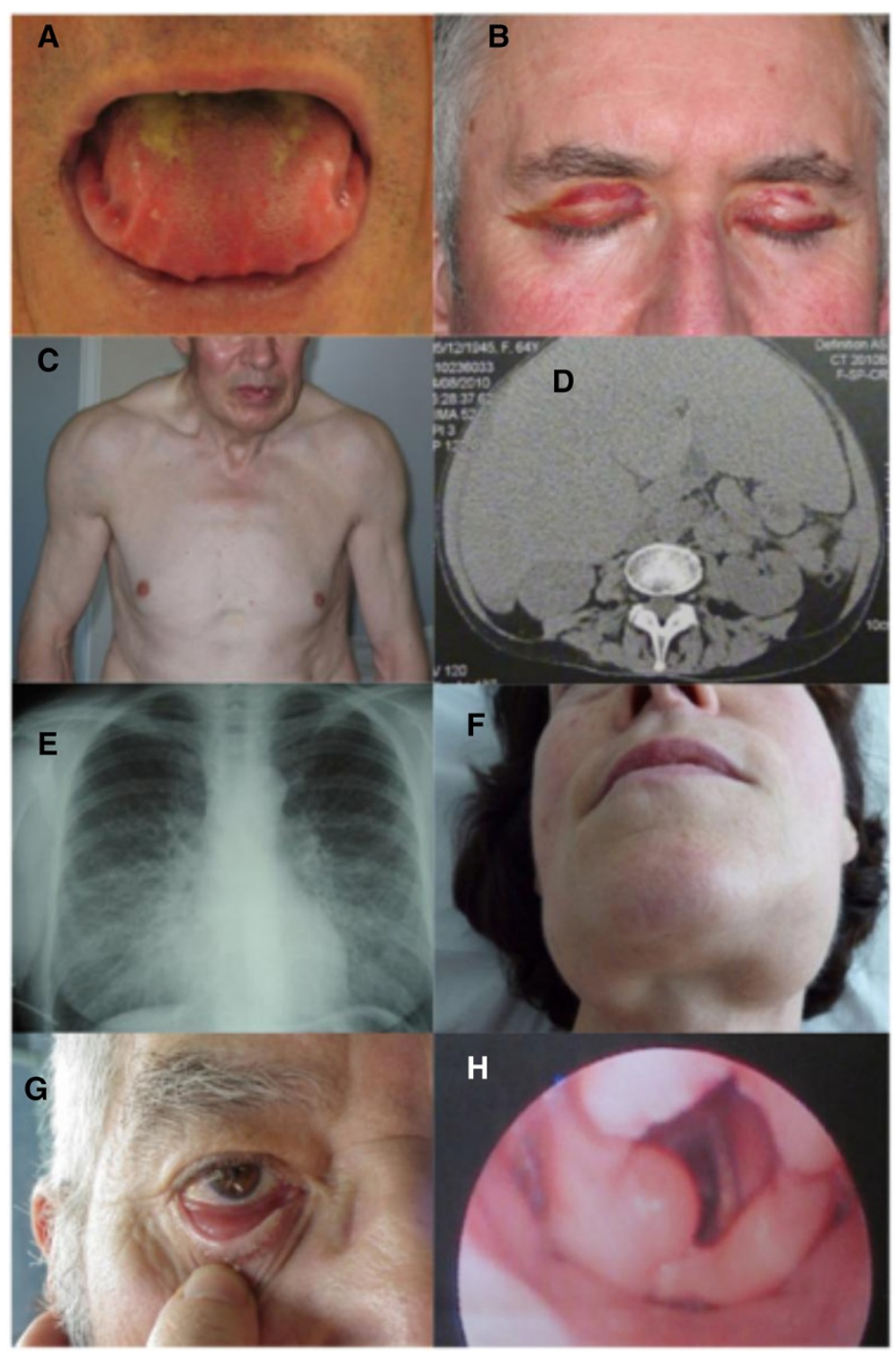

Figure 1 A-F. Systemic AL amyloidosis. A. Macroglossia with lateral scalloping of the tongue. B. Bilateral periorbital purpura. C. Pseudo athletic appearance secondary to diffuse muscular infiltration. D. Voluminous hepatomegaly due to primary hepatic amyloidosis. E. Diffuse bilateral interstitial lung disease. F. Submandibular gland enlargement. G-H. Localized AL amyloidosis. G. Nodular conjunctival amyloidosis. H. Laryngeal supraglottic amyloid lump.

or tissues involved in localized AL amyloidosis $[15,18,19]$ (Figure $1 \mathrm{G}-\mathrm{H})$.

\section{Etiology}

AL amyloidosis results from extra-cellular deposition of fibril-forming monoclonal Ig LC, usually produced by a small plasma cell clone. Indeed, the average bone marrow plasma cell infiltration is around $7 \%[20,21]$. While a dystrophic appearance of plasma cells is observed in around $70 \%$ of patients, progression towards symptomatic myeloma is exceptional. In the rare cases where $\mathrm{AL}$ amyloidosis is associated with Waldenström's disease or
non-Hodgkin B-cell lymphoma, an IgM paraprotein is often detected [14]. In spite of the small tumour burden of plasma cell proliferation, cytogenetic abnormalities are observed with virtually the same frequency as in multiple myeloma. Compared to multiple myeloma, $\mathrm{t}$ $(11 ; 14)$ translocation appears to be more frequent, probably because it is generally associated with the secretion of excess free LC [22]. A serum and/or urine monoclonal component is detectable by immunofixation and/or immunoelectrophoresis in 80 to $90 \%$ of patients. With the use of sensitive techniques, such as nephelemetric measurement of serum free light chains (FLCs) an 
abnormal concentration of serum free LCs is found in more than $90 \%$ of patients, with an overrepresentation of the $\lambda$-isotype [23].

The key event in the occurrence of amyloidosis is the change in the secondary or tertiary structure of the abnormal monoclonal LC, which enables it to obtain, as for all amyloidogenic proteins, at least two more or less stable different conformations. This conformational change is responsible for abnormal folding of the LC, rich in $\beta$-sheets. The $\beta$-sheets are repetitive secondary structures, consisting of folded alignments of peptides bound by hydrogenous links between $\mathrm{NH}$ and $\mathrm{CO}$ groups. These links occur between two different regions of the peptide strands, or between two different peptide strands, and facilitate formation of oligomers and their precipitation. The amyloid substance is made up of stacked protein monomers rich in $\beta$-sheets, which form proto-filaments 2 to $5 \mathrm{~nm}$ in diameter that make up fibrils. Amyloid fibrils display the appearance of a steel cable made of clusters of 2 to 6 proto-filaments plaited together. In all cases, the stacking is perpendicular to the axis of the proto-filament $\beta$-sheets and generates a material that specifically stains with Congo red or thioflavin $[1,24,25]$.

Not all LC are amyloidogenic. Several characteristics indicate that LC primary structure are involved in the propensity to form amyloid, including the overrepresentation of lambda LC ( 2 to 4 times more frequent than kappa LC), and the association of homology family of $\mathrm{LC} \mathrm{V}$ region with organ tropism. For example the V $\lambda \mathrm{VI}$ variability subgroup is expressed exclusively in amyloidassociated monoclonal Ig and represents $41 \%$ of amyloidogenic $\lambda$-chains [26]. V $\lambda$ VI LC are frequently associated with renal involvement. On the contrary expression of the IGVL1-44 gene increased 5 times the odds of major heart disease, [27], and kappa LC are more frequent in patients with predominant hepatic disease $[28,29]$.

As amyloid deposits assemble in various locations, they generate a wide range of clinical symptoms. It is usually considered that organ dysfunction is dependent on the mechanical effect of deposits, as demonstrated by the characteristic thickened rigidified cardiac muscle in advanced amyloid heart disease. More recently, some observations have suggested a direct toxic effect of monoclonal light chains in some tissues. In patients with severe amyloid heart disease, in whom rapid and complete hematological response is obtained with chemotherapy, spectacular improvement of cardiac symptoms may be observed. It is accompanied by rapid decrease in serum Nt-proBNP level, a sensitive marker of cardiac involvement [30], whereas cardiac deposits remain unchanged on echocardiography. Amyloid LCs isolated from patients with amyloid cardiomyopathy have been shown to specifically provoke oxidative stress, cellular dysfunction and apoptosis in isolated adult cardiomyocytes through activation of p38 mitogen-activated protein kinase (MAPK) [31,32].

\section{Diagnosis}

\section{Diagnosis of $\mathrm{AL}$ amyloidosis}

The diagnosis of amyloid is based on the finding, by light microscopic examination, of amorphous extracellular Congo red positive deposits, which display characteristic dichroism and apple green birefringence under polarised light. Congo red staining may be falsely negative if tissue sections are less than $5 \mu \mathrm{m}$ in thickness. Whenever possible, non-invasive biopsies of abdominal fat [33,34] and minor salivary glands [35] should be performed initially. If necessary, i.e. when tissue biopsies fail to demonstrate amyloid deposition, or are insufficient for amyloid typing, biopsy of a clinically affected organ (kidney, liver, gastrointestinal tract, endomyocardial tissue) should be considered. When a kidney biopsy is performed in patients with renal involvement, it allows identification of Ig LC amyloid deposits in more than $80 \%$ of cases [36]. Deposits predominate in the mesangium and along the glomerular basement membranes. Interstitial and vascular deposits are frequently observed, but they are rarely isolated (Figure 2 A-E). Electron microscopy may be useful to confirm the presence of amyloid deposits, that typically display the ultrastructural appearance of randomly arranged fibrils, 7 to $10 \mathrm{~nm}$ in external diameter [37-39] (Figure 2F).

The persistence of Congo-red positivity after treatment of biopsy samples with potassium permanganate is suggestive, but not specific of AL amyloidosis. Furthermore, the presence of a serum or urine paraprotein is not sufficient to establish the diagnosis of AL amyloidosis, because of the frequency of monoclonal gammopathies in patients aged over 50 years [40]. Whenever possible, efforts should be made to correctly identify the immunoglobulinic composition of amyloid deposits. Amyloid typing relies primarily on immunohistochemistry on paraffin-embedded tissue sections, and immunofluorescence microscopy on frozen sections showing staining of deposits with a conjugate specific for kappa or lambda LC (Figure $2 \mathrm{C}-\mathrm{E}$ ). Immunofluorescence appears to be more reliable for the diagnosis of AL amyloidosis, with a higher rate of successful typing than immunohistochemistry (65 to 85\%, versus 38 to $87 \%$, respectively) [37]. However, due to local proteolysis, LC in amyloid deposits often display partial or complete deletion of the constant domain, which is recognized by most commercial antibodies. Therefore, adequate immunohistochemical diagnosis of AL requires evaluation by experienced laboratories in which a large panel of antibodies specific for lambda and kappa LC is available, to maintain high diagnostic sensitivity and specificity $[37,38]$. In specialized centres, identification of deposits may be achieved using immunoelectron microscopy [41] (Figure 2 G,H), or mass spectroscopic-based 

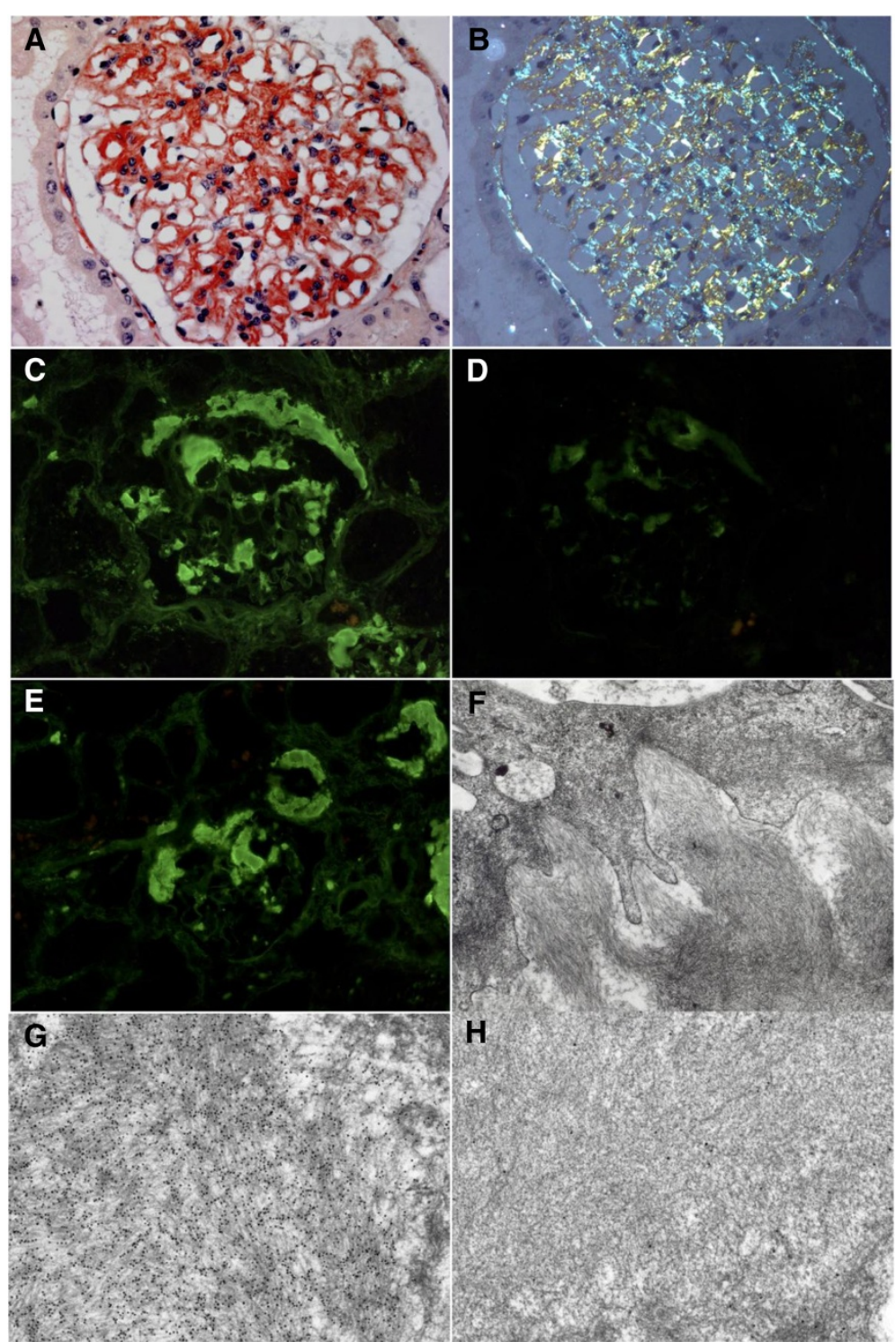

H

Figure 2 Systemic AL amyloidosis. Kidney biopsy. A,B. Light microscopy (Congo red staining, original magnification x 400). Congo red-positive glomerular deposits in the mesangium, capillary walls and Bowman's capsule (A), with typical apple-green birefringence under polarized light (B). C-E. Immunofluorescence (original magnification x 400). Glomerular amyloid deposits positively stained with the anti-lambda conjugate (C), but not with the anti-kappa conjugate (D). E. Glomerular and arteriolar amyloid deposits showing similar strong staining with the anti-lambda conjugate. F. Electron microscopy (original magnification x 8.000). Glomerular subepithelial amyloid deposits organized into randomly arranged fibrils 7 to $10 \mathrm{~nm}$ in external diameter. G,H. Immunoelectron microscopy (original magnification, X 30.000). Glomerular amyloid deposits decorated by $10 \mathrm{~nm}$ gold-conjugated anti-lambda antibody (G). No staining was observed with gold-conjugated anti-kappa antibody (H).

proteomic analysis of deposits after laser dissection of paraffin embedded samples. This new specific and sensitive method, readily applicable in a clinical setting, allows rapid typing of amyloid in most cases. Although it is currently used only in specialized centres, it might decrease the percentage of non-typable amyloidosis in the near future [42].

\section{Diagnosis of amyloid heart involvement}

The diagnosis of amyloid heart disease relies on the association of electrocardiographic and echographic signs.
ECG signs, including microvoltage (QRS size $<0.5 \mathrm{~cm}$ ) in peripheral derivations and $\mathrm{Q}$ waves in precordial derivations, are particularly suggestive if they are accompanied by cardiac hypertrophy. Ultrasound abnormalities are characterized by a shiny and grainy aspect of the interventricular septum, with concentric cardiac hypertrophypredominating in the left ventricle. A septum thickness $>15 \mathrm{~mm}$ in diastole indicates advanced amyloid heart disease, associated with a median survival of only 6 months if not treated. Measurement of the left 
ventricular ejection fraction, and dilatation of the left atrium are also prognostic markers [6,7,10-12]. New techniques, such as diastolic color Doppler myocardial velocity imaging and strain rate imaging, should improve early detection of left ventricular dysfunction in patients with AL amyloid heart disease [43]. Late gadolinium enhancement-cardiac magnetic resonance may also detect early cardiac abnormalities in patients with amyloidosis with normal left ventricular thickness [44]. Troponins T and I, B natriuretic peptide (BNP) or its $\mathrm{N}$-terminal fraction (NT-proBNP) [30,45], and more recently, highsensitivity cardiac troponin $\mathrm{T}[46,47]$, are all sensitive markers of diastolic dysfunction and represent reliable prognostic markers in AL amyloidosis. Recently, it has been proposed a prognostic score based on the serum levels of troponin $\mathrm{T}$ and NT-proBNP, with 3 stages defined by normal serum levels of troponin $\mathrm{T}$ and NTproBNP (stage 1), increase in one marker level (stage 2), or in both (stage 3) with tresholds at $332 \mathrm{ng} / \mathrm{l}$ for NTproBNP and 0,035 $\mu \mathrm{g} / \mathrm{l}$ for troponine $\mathrm{T}$ [45].

\section{Differential diagnosis}

Systemic AL amyloidoisis should be distinguished from other forms of amyloidosis, related to different protein precursors bearing an unstable tertiary structure enabling the formation of fibrils. Various mechanisms of amyloid deposition are involved in systemic amyloidosis: increased serum levels of serum amyloid A protein (SAA) in AA amyloidosis during chronic inflammatory or infectious diseases, or increased $\beta 2$ microglobulin levels in chronic dialysis patients. In hereditary amyloidosis, a mutation in the gene encoding for the precursor results in increased amyloidogenicity of the mutant protein. Although the transmission of all types of hereditary amyloidosis is autosomal dominant, a suggestive family history is often lacking due to incomplete penetrance of the mutation [48]. Therefore, in the absence of unequivocal staining with an anti-LC antibody, additional immunofluorescence and immunohistochemistry studies should be performed to verify the absence of staining with antibodies specific for amyloid precursors found in hereditary amyloidosis (i.e. lysozyme, apolipoprotein A1, apoliprotein A2, fibrinogen, gelsolin and transthyretin). Moreover, genetic studies seeking for an amyloidogenic mutation of the genes encoding for the precursors cited above should be rapidly undertaken, with, if available, mass spectrometry-based proteomic analysis of biopsy samples after laser microdissection.

AL amyloidosis should be also differentiated from Randall-type LCDD, a systemic disease characterized by LC deposition, along basement membranes in most tissues. Kidney involvement is nearly constant. Most patients present with symptoms of glomerular disease, including proteinuria with nephrotic syndrome in around half of the cases, and nearly constant impaired renal function. By contrast with AL amyloidosis, hypertension and microscopic hematuria are more commonly observed, whereas extra-renal manifestations, including heart and liver disease are rarely symptomatic at presentation. Furthermore, LCDD is associated with multiple myeloma is 30 to $60 \%$ of the cases, and a monoclonal Ig is detectable in the serum and/or urine in up to $90 \%$ of patients $[49,50]$. Diagnosis of LCCD is usually made after pathological examination of a kidney biopsy. Tubular lesions are constant, characterized by Congo red-negative periodic acid-Schiff-positive deposits along basement membranes, usually associated with marked interstitial fibrosis, and in two thirds of cases, with nodular glomerulosclerosis. Immunofluorescence study is mandatory to confirm the diagnosis, showing linear continuous deposits along tubular basement membranes, and, in most cases, along glomerular basement membranes and around arteriolar myocytes. At variance with $\mathrm{AL}$ amyloidosis, the $\mathrm{K}$ LC isotype is 2 to 3 times more frequent than the $\lambda$ isotype, with a predominance of the Vk4 subgroub [51]. Electron microscopy typically shows granular, non organized electron dense deposits with a linear distribution along tubular, glomerular and arteriolar basement membranes $[39,49,50]$.

\section{Management including treatment}

\section{Specific treatment}

Treatment of systemic AL amyloidosis relies mainly on chemotherapy aimed at suppressing the underlying plasma cell clone secreting amyloid-forming Ig LC. AL amyloidosis results from a balance between amyloid deposition and clearance of deposits. The decrease or halting in the production of amyloidogenic proteins thanks to the treatment moves the balance towards the tissue catabolism of deposits [1]. The degree of reduction of monoclonal protein secretion required for regression of amyloid deposits depends on individual factors and on the affected organ: a decrease in hepatic deposits will often be apparent within 3 or 4 months, even if the reduction in serum free LC levels is not complete, whereas regression of amyloid infiltration of the cardiac muscle will take several years.

Therefore, treatment of $\mathrm{AL}$ amyloidosis is equal to treatment of the underlying plasma cell, lymphoplasmocytic or lymphoproliferative disorder that is responsible for the secretion of the amyloid precursor. All treatment strategies which have shown efficiency in multiple myeloma or in lymphoproliferative disorders can be used, adapted to the type of the causal haematological disease, to the nature and number of affected organs, and bearing in mind their potential toxicity. The goal of treatment should be the achievement of hematologic response, partial response which is now defined by a $\geq 50 \%$ reduction 
Table 2 Updated hematologic (immunochemical) response criteria

\begin{tabular}{ll}
\hline Hematologic response & Criteria \\
\hline Complete response (CR) & $\begin{array}{l}\text { Negative serum and urine IFE, } \\
\text { normal k/I ratio }\end{array}$ \\
$\begin{array}{l}\text { Very good partial response (VGPR) } \\
\text { Partial response (PR) }\end{array}$ & $\mathrm{dFLC}<40 \mathrm{mg} / \mathrm{l}$ \\
No response (NR) & Other \\
\hline
\end{tabular}

Abbreviations: IFE, immunofixation electrophoresis; $d F L C$, difference in concentration between involved and uninvolved free light chains From Gertz et al. ( 3,4$)$ with permission.

in the difference between involved and uninvolved FLC (dFLC), very good partial response (VGPR) by a dFLC less than $40 \mathrm{mg} / \mathrm{l}$, and complete response (CR) being assessed by the absence of detectable monoclonal Ig with normal sFLCs and kappa/lambda ratio (Table 2) [3-5].

Only 15 years ago, overall survival in AL amyloidosis was poor, as demonstrated in two randomized studies which showed that a combination of melphalan plus prednisone (MP) had limited beneficial effect, with a median overall survival of 18 months, compared to 12 months in patients who received no treatment or colchicine therapy alone $[52,53]$. Since then, the prognosis of the disease has been transformed with the development of new strategies that efficiently suppress the secretion of the amyloid forming LCs. Table 3 and 4 report the results of high dose mephalan followed by autologous blood stem cell transplantation (HDM/SCT) and conventional treatment studies in AL amyloidosis [54-67].

\section{HDM/SCT}

The feasibility and efficacy of HDM/SCT in systemic AL amyloidosis was first demonstrated by Ray Comenzo and colleagues [68,69]. The protocol includes a step of stem cell collection after mobilization through injections of G-CSF-type growth factor, followed by high-dose melphalan of 100 to $200 \mathrm{mg} / \mathrm{m}^{2}$, depending on the patient's age and extent of disease. In experienced centers, this strategy results in a haematological response rate of more than 60\%, including $40 \%$ complete responses (CR), and a median survival around 4.5 years [54]. However, due to the high toxicity of HDM/SCT, only certain patients benefit; indeed, treatment-related mortality (TRM) approaches 10\% even in the largest centers after careful patient selection. In a recent review of 421 consecutive patients treated with HDM/SCT, TRM was $11.4 \%$ for all patients over 15 years, and $5.3 \%$ in the last 5 years, with improved patient selection and experienced management [57]. Whether HDM/SCT should be followed by consolidation and maintenance therapy to improve quality and duration of hematologic responses remains to be established; in a recent phase II study, consolidation with bortezomib and dexamethasone following risk-adapted HDM/SCT resulted in high overall and stringent complete response rates (59 and 28\%, respectively), with good tolerance [70].

However, although more than 50 studies have confirmed its efficacy over the last ten years, HDM/SCT in AL amyloidosis remains restricted to selected patients, generally those aged less than 65 years, with a maximum of two organs involved and without advanced cardiac amyloidosis. As eligibility for hematopoietic stem-cell transplantation has been shown to be a favourable prognostic factor for survival [71], the place of HDM/SCT as firstline therapy in systemic AL amyloidosis is questionable.

\section{Conventional chemotherapy}

In parallel, several studies have shown the efficacy of highdose dexamethasone-based regimens at inducing haematological responses and prolonging survival. Unexpected efficacy, close to that of HDM/SCT, was reported with the vincristin-adriamycin-dexamethasone (VAD) and melphalan dexamethasone (M-Dex) regimens [21,61].

Table 3 Results of main multicenter and single-center studies of HDM/SCT in AL amyloidosis

\begin{tabular}{|c|c|c|c|c|c|}
\hline Authors (references) & $\begin{array}{l}\text { Year of publication } \\
\text { and } N^{\circ} \text { of patients }\end{array}$ & $\begin{array}{l}\text { Clonal response\% } \\
(\mathrm{PR}+\mathrm{CR})\end{array}$ & CR\% & TRM\% & $\begin{array}{l}\text { Median } \\
\text { survival } \\
\text { (years) }\end{array}$ \\
\hline \multicolumn{6}{|l|}{ Single center studies } \\
\hline Skinner et al. [54] & $2004 / 312$ & NA & $40 * *$ & 13 & $4,6^{* *}$ \\
\hline Sanchorawala et al. [55] & $2007 / 80$ & NA & $37^{* *}$ & 18 & $4,75 * *$ \\
\hline Schonland et al. [56] & $2010 / 58$ & $74 *$ & $46 *$ & 17 & $>8 *$ \\
\hline Cibeira et al. [57] & $2011 / 421$ & NA & $34 * *$ & 11,4 & $6,3 * *$ \\
\hline Madan et al. [58] & 2012/187 & $66 * *$ & $30 * *$ & 15 & $4,5^{* *}$ \\
\hline \multicolumn{6}{|l|}{ Multicenter studies } \\
\hline Vesole et al. [59] & 2003/107 & $32 * *$ & $16 * *$ & 27 & $3,9^{* *}$ \\
\hline Goodman et al. [60] & $2006 / 92$ & $66^{* *}$ & $35 * *$ & 23 & $5,3^{* *}$ \\
\hline Jaccard et al. [21] & $2007 / 50$ & $36 *$ & $22 *$ & 26 & $1,8 *$ \\
\hline
\end{tabular}

* Intent to treat after inclusion in an intensive treatment program **only after intensive treatment. 
Table 4 Results of main studies of conventional treatment in AL amyloidosis

\begin{tabular}{|c|c|c|c|c|c|c|}
\hline Authors (references) & Regimen & $\begin{array}{l}\text { Year of publication } \\
\text { and } \mathrm{N}^{\circ} \text { of patients }\end{array}$ & $\begin{array}{l}\text { Clonal response \% } \\
(\mathrm{PR}+\mathrm{CR})\end{array}$ & CR\% & TRM\% & $\begin{array}{l}\text { Median survival } \\
\text { (years) }\end{array}$ \\
\hline Palladini et al. [61] & M-Dex & $2004 / 46$ & 67 & 33 & 4 & 5,1 \\
\hline Jaccard et al. [21 & M-Dex & $2007 / 50$ & 68 & 31 & 2 & 4,6 \\
\hline Wechalekar et al. [62] & CTD & $2007 / 75$ & 74 & 21 & 4 & 3,4 \\
\hline Moreau et al. [63] & M-Dex -Lenalidomide & $2010 / 26$ & 58 & 23 & 0 & $80 \%$ at 2 years \\
\hline Kastridis et al. [64] & Bortezomib +-dexamethasone & 2010/94 & 71 & 25 & 0 & $76 \%$ at 1 year \\
\hline Reece et al. [65] & Bortezomib & $2011 / 33$ & 66 & 24 & 6 & $80 \%$ at 1 year \\
\hline Mickael et al. [66] & CyBorD & 2012/17 & 94 & 71 & 0 & $70 \%$ at 21 months \\
\hline Venner et al. [67] & CVD & $2012 / 43$ & 81 & 41 & 0 & $97 \%$ at 2 years \\
\hline
\end{tabular}

Abbreviations; M-Dex : melphalan + dexamethasone, CTD : cyclophosphamide + thalidomide + dexamethasone, CyborD and CVD :

cyclophosphamide + bortezomib + dexamethasone.

M-Dex consists of melphalan $10 \mathrm{mg} / \mathrm{m} 2 /$ day and dexamethasone $40 \mathrm{mg} /$ day, 4 days/month, of which doses should be adapted according to glomerular filtration rate and age. The M-Dex association is more rapidly effective than the classical Melphalan plus Prednisone regimen, as it allows a 58 to $67 \%$ haematological response rate, including 13 to $33 \%$ of complete responses and clinical responses in $50 \%$ of patients $[21,61,72]$. Due to a low toxicity profile, with a TRM between 2 and 7\%, dexamethasone-based regimens may be used even in patients with advanced disease. In 2007, a French multicentre randomized prospective trial showed that, compared to HDM/SCT, M-Dex had similar efficacy with less toxicity, resulting in increased survival. One hundred patients with newly diagnosed AL amyloidosis were randomly assigned to receive intravenous high-dose melphalan $\left(200 \mathrm{mg} / \mathrm{m}^{2}\right.$, tapered down to $140 \mathrm{mg} / \mathrm{m}^{2}$ in patients aged over 65 years and in those with advanced heart, kidney or liver disease), followed by SCT, or oral M-Dex, 4 days per month. Although hematologic and organ responses did not differ significantly between the two treatment groups, the mortality rate in the first 100 days was higher in the group assigned to receive HDM/SCT. After a median follow-up of 3 years, in the intentionto-treat analysis, the estimated overall survival was 22.2 months in the HDM/SCT group, and 56.9 months in the group assigned to received oral M-Dex $(P=0.04)$. Overall survival was non-significantly different in the two groups, among patients with high-risk disease and among those with low-risk disease. Furthermore, a landmark analysis showed that survival was also similar in patients who survived at least 6 months after randomization and who received their assigned treatment [21].

Therefore, the place of HDM/SCT as first-line treatment for systemic AL amyloidosis is currently debated. Whereas it is still commonly employed in the USA in young patients without severe disease, it is no longer used in most European countries except Germany, and M-Dex represents the most common chemotherapy regimen in European patients with systemic AL amyloidosis associated with an IgG, IgA or isolated LC monoclonal gammopathy. There is currently no consensus on the duration of treatment with M-Dex, which should be carefully evaluated in each individual case. In patients who achieve a haematological response (usually after a median of 2 to 4 cycles), treatment is usually maintained for 3 additional cycles, in order to increase the duration of remission. M-Dex should be given for no longer than 9 to 12 months, in order to reduce the risk of secondary myelodysplasia and acute non-lymphocytic leukaemia [73].

In patients with underlying lymphoplasmocytic proliferation, (usually associated with an IgM monoclonal gammopathy), treatment regimens are identical to those used in Waldenström's disease, i.e. Fludarabine-CyclophosphamideRituximab, Cyclophosphamide-Dexamethasone-Rituximab or Bortezomib-Dexamethasone-Rituximab. HDM/SCT also appears to be effective $[14,74]$.

As the regression of amyloid deposits is slow, surveillance and evaluation of treatment rely on serial measurements of serum monoclonal immunoglobulin level, at best by the dosage of serum FLCs. In spite of the slow elimination of deposits, the global response to treatment has to be regularly assessed in terms of clinical response, which determines both short-term (symptomatic amyloid heart disease) and long-term prognosis (progression of chronic kidney disease). Criteria for organ response are given in Table 5. Routine measurements of serum NTproBNP levels in patients with cardiac involvement is important, as a $30 \%$ decrease in serum level after 3 cycles of chemotherapy is predictive of a favourable outcome $[30,45,46]$.

\section{Novel agents}

In the absence of haematological response, prognosis is rapidly engaged and the more serious the disease (e.g.: symptomatic heart disease), the quicker the treatment has to be modified. Several preliminary studies have shown encouraging results with novel anti-myeloma drugs such 
Table 5 Updated organ response criteria

\begin{tabular}{|c|c|}
\hline Organ & Response criteria \\
\hline Heart & $\begin{array}{l}\text { Mean interventricular septal thickness decreased } \\
\text { by } 2 \mathrm{~mm}, 20 \% \text { improvement in ejection fraction, } \\
\text { improvement by } 2 \text { NYHA classes without an increase } \\
\text { in diuretic use, and no increase in wall thickness and/or } \\
\text { a reduction ( } \geq 30 \% \text { and } \geq 300 \mathrm{ng} / \mathrm{L} \text { ) of NT-proBNP } \\
\text { in patients in whom the eGFR is } \geq 45 \mathrm{~mL} / \mathrm{min} / 1.73 \mathrm{~m} 2\end{array}$ \\
\hline Kidney & $\begin{array}{l}50 \% \text { decrease (at least } 0.5 \mathrm{~g} / \text { day) of } 24 \text {-hr urine protein } \\
\text { (urine protein must be }>0.5 \mathrm{~g} / \text { day pre-treatment) } \\
\text { in the absence of a reduction in eGFR } \geq 25 \% \text { or an } \\
\text { increase in serum creatinine } \geq 0.5 \mathrm{mg} / \mathrm{dL}\end{array}$ \\
\hline \multirow[t]{2}{*}{ Liver } & $50 \%$ decrease in abnormal alkaline phosphatase value \\
\hline & Decrease in liver size radiographically at least $2 \mathrm{~cm}$ \\
\hline
\end{tabular}

Abbrevations : NYHA : New York Heart Association; NT-pro BNP, N-terminal probrain natriuretic peptide; eGFR, estimated glomerular filtration rate; $N B$ : widely available methods for defining peripheral and autonomic nervous system response were felt not to exist.

From Gertz et al. ( 3,4$)$ with permission.

as thalidomide, lenalidomide and the proteasome inhibitor bortezomib [62-67,75-80]. Combined with dexamethasone, these agents induce rapid haematological responses in most patients, even in those with refractory or relapsing disease. The cyclophosphamide, thalidomide and dexamethasone regimen appears to produce similar results as M-Dex alone [62], whereas the combination of M-Dex with lenalidomide slightly increases haematological response rates [63]. A striking difference has been observed with the introduction of bortezomib, which results in clonal response rates of $70-90 \%$, including around $40 \%$ of CR. Furthermore, the bortezomib plus dexamethasone regimen has shown remarkable efficacy in previously treated patients with refractory disease. These high hematological response rates are achieved with manageable toxicity and within a relatively short time span [64-67,77-80]. In a recent phase II study, M-Dex plus bortezomib induced a $94 \%$ haematological response rate, with $60 \%$ CR [80]. This combination will be soon compared to M-Dex in an international randomized trial. Bortezomib may also be combined with cyclophosphamide and dexamethasone with a good tolerance and impressive response rates $(74,75)$. Bortezomib has to be used with caution in patients with advanced amyloid heart disease, who may occasionally develop abrupt reduction in left ventricular ejection fraction. Nevertheless, due to their superior tolerability and efficacy compared to ASCT and M-Dex, bortezomib-based regimens will probably become first-line therapy in systemic AL amyloidosis in the near future.

\section{Localized AL amyloidosis}

In patients with localized AL amyloidosis, local therapy, mainly based on surgical or laser excision, is usually efficient, and, in most cases, systemic chemotherapy is not required. In some patients with life-threatening symptoms due to local obstruction (namely of the upper airways), local radiotherapy should be considered to eradicate the underlying LC producing clone $[18,19,81]$.

\section{Symptomatic treatment}

Apart from specific treatment of the underlying haematological disease, symptomatic measures and supportive care is necessary in patients with organ failure. Most drugs commonly used for the treatment of cardiac failure (i.e. calcium inhibitors, $\beta$-blockers, angiotensin converting enzyme inhibitors) are inefficient or even dangerous in patients with amyloid heart disease. Digitalics, which should be used cautiously, are only indicated for the treatment of rapid arrhythmia. Loop diuretics are useful, when given at high dosage in patients with severe fluid retention. Amiodarone should be considered as first line therapy for arrhythmia. Pacemaker implantation may be indicated in patients who develop symptomatic bradycardia or conduction disorders. Finally, cardiac transplantation should be considered in selected patients with advanced amyloid cardiopathy [10-12,82,83].

Clinical follow-up of amyloid nephropathy is based on routine surveillance of serum creatinine, urea, total proteins, albumin, and 24-hour proteinuria. In patients with nephrotic syndrome, control of fluid retention relies on loop diuretics, often given at a high dose, or combined with other diuretics. Nephrotic syndrome may persist in patients with end-stage renal disease (ESRD) and require therapeutic intervention to stop diuresis. In a recent series, $13 \%$ out of 752 patients with an estimated glomerular filtration rate $>15 \mathrm{ml} / \mathrm{min}$ at baseline progressed to end-stage renal disease (ESRD), after a median time of 26.8 months [8]. Chronic dialysis is indicated in patients with AL amyloidosis and ESRD, hemodialysis and peritoneal dialysis being associated with similar survival. Kidney transplantation may also be offered to selected patients who have achieved persistent haematological remission, at least for one year [82]. When solid organ transplantion is considered (heart, liver, kidney), it should be necessarily preceded or followed by chemotherapy in order to avoid systemic progression and amyloid recurrence on the implanted organ [82-85].

Very few effective treatments are currently available for autonomic neuropathy, often responsible for severe postural hypotension, which accounts for significant morbidity and mortality. Wearing of support stockings is recommended, together with midodrine $2.5 \mathrm{mg} \times 3 /$ day, to be increased up to $10 \mathrm{mg} \times 3 /$ day. Fludrocortisone is also worth trying, but it is often poorly tolerated as it may increase fluid retention [86].

\section{Prognosis}

In AL amyloidosis, survival depends on haematological response to therapy, on the extension and severity of 
organ involvement, and on the presence or not of amyloid heart disease. Prognosis is not influenced by the underlying plasma cell proliferation. However, identification of a neoplastic plasma cell population adversely affects survival [87], and a bone marrow plasma cell infiltration above $10 \%$ has been associated with poorer outcome [88]. AL amyloidosis is a serious disease and causes death when treatment is delayed, whereas new therapeutic strategies induce haematological remission in most patients, with a median survival of more than 5 years. Early diagnosis is therefore a critical step in the care of these patients.

\section{Unresolved questions}

In spite of the definite improvement in survival over the last few years with the development of new chemotherapy regimens, there is currently no treatment able to accelerate the catabolism of AL amyloid deposits. All available therapeutic strategies work by reducing the production of the amyloidogenic precursor, thus enabling the body to slowly eliminate existing deposits. Research is currently underway to develop treatments that would increase tissue catabolism of amyloid deposits. Serum amyloid $\mathrm{P}$ protein (SAP) is an important component of all amyloid fibrils, which stabilize fibrils and make them resistant to proteolysis. Recently, CPHPC, a molecule able to rapidly decrease circulating SAP levels has been developed [89]. The combination of this molecule with an antibody specific for SAP, which targets amyloid deposits and enables their elimination by recruiting phagocyte cells, has shown impressive results in an experimental model of systemic amyloidosis in mice [90]. A trial that will evaluate the effect of this approach for the treatment of AL amyloidosis in humans is planned in the next future.

\section{Competing interests}

Frank Bridoux: honoraria from Janssen and Celgene.

\section{Author's contribution}

All authors drafted the manuscript. All authors read and approved the final manuscript.

\footnotetext{
Author details

'Service de Néphrologie, Hémodialyse et Transplantation Rénale, CHU Poitiers, Université de Poitiers, Poitiers, Franc. ${ }^{2}$ CNRS UMR 7276, CHU Limoges, Université de Limoges, Limoges, France. ${ }^{3}$ Service d'Anatomie Pathologique, CHU Poitiers, Université de Poitiers, Poitiers, France. ${ }^{4}$ Service d'Hématologie et Immunologie, Hôpital Saint-Louis, Saint-Louis, Paris. ${ }^{5}$ Service d'Hématologie et de Thérapie Cellulaire, CHU de Limoges, 2, avenue Martin Luther King, Limoges 87042 Cedex, France.

Received: 4 May 2010 Accepted: 5 August 2012

Published: 21 August 2012

\section{References}

1. Merlini G, Bellotti V: Molecular mechanisms of amyloidosis. N Engl J Med 2003, 349:583-596.

2. Kyle RA, Linos A, Beard CM, Linke RP, Gertz MA, O'Fallon WM, Kurland LT: Incidence and natural history of primary systemic amyloidosis in
}

Olmstead County, Minesota, 1950 through 1989. Blood 1992, 79:1817-1822.

3. Gertz MA, Comenzo R, Falk RH, Fermand JP, Hazenberg BP, Hawkins PN, Merlini G, Moreau P, Ronco P, Sanchorawala V, Sezer O, Solomon A, Grateau G: Definition of organ involvement and treatment response in immunoglobulin light chain amyloidosis (AL): a consensus opinion from the 10th International Symposium on Amyloid and Amyloidosis, Tours, France, 18-22 April 2004. Am J Hematol 2005, 79:319-328.

4. Gertz MA, Merlini G: Definition of organ involvement and response to treatment in AL amyloidosis: an updated consensus opinion. Amyloid 2010, 17(Suppl 1):48-49.

5. Merlini G, Seldin DC, Gertz MA: Amyloidosis: pathogenesis and new therapeutic options. J Clin Oncol 2011, 29:1924-1933.

6. Kyle RA, Gertz MA: Primary systemic amyloidosis: clinical and laboratory features in 474 cases. Semin Hematol 1995, 32:45-59.

7. Obici L, Perfetti V, Palladini G, Moratti R, Merlini G: Clinical aspects of systemic amyloid diseases. Biochim Biophys Acta 2005, 1753:11-22.

8. Pinney JH, Lachmann HJ, Bansi L, Wechalekar AD, Gilbertson JA, Rowczenio D, Sattianayagam PT, Gibbs SD, Orlandi E, Wassef NL, Bradwell AR, Hawkins PN, Gillmore JD: Outcome in renal AL amyloidosis after chemotherapy. J Clin Oncol 2011, 29:674-681.

9. Ekelund $\mathrm{L}$ : Radiological findings in renal amyloidosis. Am J Roentgenol 1977, 129:851-853.

10. Selvanayagam JB, Hawkins PN, Paul B, Myerson SG, Neubauer S: Evaluation and management of the cardiac amyloidosis. J Am Coll Cardiol 2007, 207(50):2101-2110.

11. Kappor P, Thenappan T, Singh E, Kumar S, Greipp PR: Cardiac amyloidosis: a practical approach to diagnosis and management. Am J Med 2011, 124:1006-1015.

12. Dubrey SW, Hawkins PN, Falk RH: Amyloid diseases of the heart: assessment, diagnosis, and referral. Heart 2011, 97:75-84.

13. Loustaud-Ratti VR, Cypierre A, Rousseau A, Yagoubi F, Abraham J, Fauchais AL, Carrier P, Lefebvre A, Bordessoule D, Vidal E, Sautereau D, Jaccard A: Non-invasive detection of hepatic amyloidosis: FibroScan, a new tool. Amyloid. 2011, 18:19-24.

14. Terrier B, Jaccard A, Harousseau JL, Delarue R, Tournilhac O, Hunault-Berger M, Hamidou M, Dantal J, Bernard M, Grosbois B, Morel P, Coiteux V, Gisserot O, Rodon P, Hot A, Elie C, Leblond V, Fermand JP, Fakhouri F: The clinical spectrum of IgM-related amyloidosis: a French nationwide retrospective study of 72 patients. Medicine 2008, 87:99-109.

15. Kyle RA, Bayrd ED: Amyloidosis: review of 236 cases. Medicine 1975, 54:271-299

16. Sucker C, Hetzel GR, Grabensee B, Stockschlaeder M, Scharf RE: Amyloidosis and bleeding: pathophysiology, diagnosis, and therapy. Am J Kidney Dis 2006, 47:947-955.

17. Bouma B, Maas C, Hazenberg BP, Lokhorst HM, Gebbink MF: Increased plasmin-alpha2-antiplasmin levels indicate activation of the fibrinolytic system in systemic amyloidoses. J Thromb Haemost 2005, 5:1139-1142.

18. Biewend ML, Menke DM, Calamia KT: The spectrum of localized amyloidosis: a case series of 20 patients and review of the literature. Amyloid 2006, 13:135-142.

19. Paccalin M, Hachulla E, Cazalet C, Tricot L, Carreiro M, Rubi M, Grateau G, Roblot P: Localized amyloidosis: a survey of 35 French cases. Amyloid 2005, 12:239-245.

20. Perfetti V, Vignarelli MC, Anesi E, Garini P, Quaglini S, Ascari E, Palladini G: The degrees of plasma cell clonality and marrow infiltration adversely influence the prognosis of AL amyloidosis patients. Haematologica 1999, 84:218-221.

21. Jaccard A, Moreau P, Leblond V, Leleu X, Benboubker L, Hermine O, Recher C, Asli B, Lioure B, Royer B, Jardin F, Bridoux F, Grosbois B, Jaubert J, Piette JC, Ronco P, Quet F, Cogne M, Fermand JP: Myélome Autogreffe (MAG) and Intergroupe Francophone du Myélome (IFM) Intergroup: High-dose melphalan versus melphalan plus dexamethasone for AL amyloidosis. N Engl J Med 2007, 357:1083-1093.

22. Perfetti V, Coluccia AM, Intini D, Malgeri U, Vignarelli MC, Casarini S, Merlini $G$, Neri A: Translocation $T(4 ; 14)(p 16.3 ; q 32)$ is a recurrent genetic lesion in primary amyloidosis. Am J Pathol 2001, 158:1599-1603.

23. Lachmann HJ, Gallimore R, Gillmore JD, Carr-Smith HD, Bradwell AR, Pepys $M B$, Hawkins PN: Outcome in systemic AL amyloidosis in relation to changes in concentration of circulating free immunoglobulin light chains following chemotherapy. Br J Haematol 2003, 122:78-84. 
24. Serpell LC, Sunde M, Benson MD, Tennent GA, Pepys MB, Fraser PE: The protofilament substructure of amyloid fibrils. J Mol Biol 2000, 300:1033-1039.

25. Sunde M, Serpell LC, Bartlam M, Fraser PE, Pepys MB, Blake CC: Common core structure of amyloid fibrils by synchrotron X-ray diffraction. J Mol Biol 1997, 273:729-739.

26. Ozaki S, Abe M, Wolfenbarger D, Weiss DT, Solomon A: Preferential expression of human $\lambda$-light chain variable region subgroups in multiple myeloma, AL amyloidosis, and Waldenström's macroglobulinemia. Clin Immunol Immunopathol 1994, 71:183-189.

27. Perfetti V, Palladini G, Casarini S, Navazza V, Rognoni P, Obici L, Invernizzi R, Perlini S, Klersy C, Merlini G: The repertoire of $\lambda$ light chains causing predominant amyloid heart involvement and identification of a preferentially involved germline gene, IGLV1-44. Blood 2012, 119:144-150.

28. Comenzo RL, Zhang Y, Martinez C, Osman K, Herrera GA: The tropism of organ involvement in primary systemic amyloidosis: contributions of $\mathrm{lg}$ V(L) germ line gene use and clonal plasma cell burden. Blood 2001, 98:714-720

29. Abraham RS, Geyer SM, Price-Troska TL, Allmer C, Kyle RA, Gertz MA, Fonseca $\mathrm{R}$ : Immunoglobulin light chain variable $(\mathrm{V})$ region genes influence clinical presentation and outcome in light chain-associated amyloidosis (AL). Blood 2003, 101:3801-3808.

30. Palladini G, Lavatelli F, Russo P, Perlini S, Perfetti V, Bosoni T, Obici L, Bradwell AR, D'Eril GM, Fogari R, Moratti R, Merlini G: Circulating amyloidogenic free light chains and serum $\mathrm{N}$-terminal natriuretic peptide type $\mathrm{B}$ decrease simultaneously in association with improvement of survival in AL. Blood 2006, 107:3854-3858.

31. Brenner DA, Jain M, Pimentel DR, Wang B, Connors LH, Skinner M, Apstein CS, Liao R: Human amyloidogenic light chains directly impair cardiomyocyte function through an increase in cellular oxidant stress. Circ Res 2004, 94:1008-1010.

32. Shi J, Guan J, Jiang B, Brenner DA, Del Monte F, Ward JE, Connors LH, Sawyer DB, Semigran MJ, Macgillivray TE, Seldin DC, Falk R, Liao R: Amyloidogenic light chains induce cardiomyocyte contractile dysfunction and apoptosis via a non-canonical p38alpha MAPK pathway. Proc Natl Acad Sci U S A 2010, 107:4188-4193.

33. Libbey CA, Skinner M, Cohen AS: Use of abdominal fat tissue aspirate in the diagnosis of systemic amyloidosis. Arch Intern Med 1983, 143:1549-1552.

34. Ansari-Lari MA, Ali SZ: Fine-needle aspiration of abdominal fat pad for amyloid detection: a clinical useful test? Diagn Cytopathol 2004, 30:178-181.

35. Hachulla E, Grateau G: Diagnostic tools for amyloidosis. Joint Bone Spine 2002, 69:538-545.

36. Moumas E, Desport E, Lacombe C, Gombert JM, Goujon JM, Bridoux F, Touchard G: Systemic AL amyloidosis with renal involvement in a region of Western France. Amyloid 2010, 17(Suppl 1):151.

37. Picken MM: New insights into systemic amyloidosis: the importance of diagnosis of specific type. Curr Opin Nephrol Hypertens 2007, 16:196-203.

38. Picken MM: Amyloidosis-where are we now and where are we heading? Arch Pathol Lab Med. 2010, 134:545-551.

39. Touchard G: Ultrastructural pattern and classification of renal monoclonal immunoglobulin deposits. In Monoclonal gammopathies and the kidney. Edited by Touchard G, Aucouturier P, Hermine O, Ronco P. Dordrecht: Kluwer Academic Publishers; 2003:95-117.

40. Kyle RA, Therneau TM, Rajkumar SV, Larson DR, Plevak MF, Offord JR, Dispenzieri A, Katzmann JA, Melton $\sqcup$ 3rd: Prevalence of monoclonal gammopathy of undetermined significance. N Engl J Med 2006, 354:1362-1369.

41. Veeramachaneni R, Gu X, Herrera GA: Atypical amyloidosis: diagnostic challenges and the role of immunoelectron microscopy in diagnosis. Ultrastruct Pathol 2004, 28:75-82.

42. Vrana JA, Gamez JD, Madden BJ, Theis JD, Bergen HR 3rd, Dogan A: Classification of amyloidosis by laser microdissection and mass spectrometry-based proteomic analysis in clinical biopsy specimens. Blood 2009, 114:4957-4959.

43. Al-Zahrani GB, Bellavia D, Pellikka PA, Dispenzieri A, Hayman SR, Oh JK, Miyazaki C, Miller FA Jr: Doppler myocardial imaging compared to standard two-dimensional and Doppler echocardiography for assessment of diastolic function in patients with systemic amyloidosis. J Am Soc Echocardiogr 2009, 22:290-298.
44. Syed IS, Glockner JF, Feng D, Araoz PA, Martinez MW, Edwards WD, Gertz MA, Dispenzieri A, Oh JK, Bellavia D, Tajik AJ, Grogan M: Role of cardiac magnetic resonance imaging in the detection of cardiac amyloidosis. JACC Cardiovasc Imaging 2010, 3:155-164.

45. Dispenzieri A, Gertz MA, Kyle RA: Serum cardiac troponins and N-terminal pro-brain natriuretic peptide: a staging system for primary systemic amyloidosis. J Clin Oncol 2004, 22:3751-3757.

46. Palladini G, Barassi A, Klersy C, Pacciolla R, Milani P, Sarais G, Perlini S, Albertini R, Russo P, Foli A, Bragotti LZ, Obici L, Moratti R, Melzi d'Eril GV, Merlini G: The combination of high-sensitivity cardiac troponin T (hsCTnT) at presentation and changes in N-terminal natriuretic peptide type $\mathrm{B}$ (NT-proBNP) after chemotherapy best predicts survival in AL amyloidosis. Blood 2010, 116:3426-3430.

47. Kristen AV, Giannitsis E, Lehrke S, Hegenbart U, Konstandin M, Lindenmaier D, Merkle C, Hardt S, Schnabel PA, Röcken C, Schonland SO, Ho AD, Dengler TJ, Katus HA: Assessment of disease severity and outcome in patients with systemic light-chain amyloidosis by the high-sensitivity troponin $\mathrm{T}$ assay. Blood 2010, 116:2455-2461.

48. Hawkins PN: Hereditary systemic amyloidosis with renal involvement. J Nephrol 2003, 16:443-448

49. Lin J, Markowitz GS, Valeri AM, Kambham N, Sherman WH, Appel GB, D'Agati VD: Renal monoclonal immunoglobulin deposition disease: the disease spectrum. J Am Soc Nephrol 2001, 12:1482-1492.

50. Nasr SH, Valeri AM, Cornell LD, Fidler ME, Sethi S, D'Agati VD, Leung N: Renal monoclonal immunoglobulin deposition disease: a report of 64 patients from a single institution. Clin J Am Soc Nephrol 2012, 7:231-239.

51. Preud'homme JL, Cogne M, Bauwens M, Touchard G, Aucouturier P: Structure of a monoclonal kappa chain of the VkappalV subgroup in the kidney and plasma cells in light chain deposition disease. $J$ Clin Invest 1991, 87:2186-2190.

52. Skinner $M$, Anderson J, Simms R, Falk R, Wang M, Libbey $C$, Jones LA, Cohen AS: Treatment of 100 patients with primary amyloidosis: a randomized trial of melphalan, prednisone, and colchicine versus colchicine only. Am J Med 1996, 100:290-298.

53. Kyle RA, Gertz MA, Greipp PR, Witzig TE, Lust JA, Lacy MQ, Therneau TM: A trial of three regimens for primary amyloidosis: colchicine alone, melphalan and prednisone, and melphalan, prednisone, and colchicine. N Engl J Med 1997, 336:1202-1207.

54. Skinner M, Sanchorawala V, Seldin DC, Dember LM, Falk RH, Berk JL, Anderson JJ, O'Hara C, Finn KT, Libbey CA, Wiesman J, Quillen K, Swan N, Wright DG: High-dose melphalan and autologous stem-cell transplantation in patients with AL amyloidosis: an 8-year study. Ann Intern Med 2004, 140:85-93.

55. Sanchorawala V, Skinner M, Quillen K, Finn KT, Doros G, Seldin DC: Longterm outcome of patients with $\mathrm{AL}$ amyloidosis treated with high-dose melphalan an stem-cell transplantation. Blood 2007, 110:3561-3563.

56. Schonland SO, Bochtler T, Perz J, et al: Results of two consecutive phase II trials of patients with systemic $\mathrm{AL}$ amyloidosis treated with high-dose melphalan after induction and mobilization chemotherapy [12th international symposium on amyloidosis abstracts]. Amyloid 2010, $17: 80-81$

57. Cibeira MT, Sanchorawala V, Seldin DC, Quillen K, Berk JL, Dember LM, Segal A, Ruberg F, Meier-Ewert H, Andrea NT, Sloan JM, Finn KT, Doros G, Blade J, Skinner M: Outcome of AL amyloidosis after high-dose melphalan and autologous stem cell transplantation: long-term results in a series of 421 patients. Blood 2011, 118:4346-4352.

58. Madan S, Kumar SK, Dispenzieri A, Lacy MQ, Hayman SR, Buadi FK, Dingli D, Rajkumar SV, Hogan WJ, Leung N, Grogan M, Gertz MA: High-dose melphalan and peripheral blood stem cell transplantation for light-chain amyloidosis with cardiac involvement. Blood 2012, 119:1117-1122.

59. Vesole DH, Pérez WS, Akasheh M, Boudreau C, Reece DE, Bredeson CN: Plasma Cell Disorders Working Committee of the Center for International Blood and Marrow Transplant Research. High-dose therapy and autologous hematopoietic stem cell transplantation for patients with primary systemic amyloidosis: a Center for International Blood and Marrow Transplant Research Study. Mayo Clin Proc 2006, 81:880-888,

60. Goodman HJ, Gillmore JD, Lachmann HJ, Wechalekar AD, Bradwell AR, Hawkins PN: Outcome of autologous stem cell transplantation for AL amyloidosis in the UK. Br J Haematol 2006, 134:417-425.

61. Palladini G, Perfetti V, Obici L, Caccialanza R, Semino A, Adami F, Cavallero G, Rustichelli R, Virga G, Merlini G: Association of melphalan and high- 
dose dexamethasone is effective and well tolerated in patients with AL (primary) amyloidosis who are ineligible for stem cell transplantation. Blood 2004, 103:2936-2938.

62. Wechalekar AD, Goodman HJ, Lachmann HJ, Offer M, Hawkins PN, Gillmore JD: Safety and efficacy of risk-adapted cyclophosphamide, thalidomide, and dexamethasone in systemic AL amyloidosis. Blood 2007, 109:457-464.

63. Moreau P, Jaccard A, Benboubker L, Royer B, Leleu X, Bridoux F, Salles G, Leblond V, Roussel M, Alakl M, Hermine O, Planche L, Harousseau JL, Fermand JP: Lenalidomide in combination with melphalan and dexamethasone in patients with newly diagnosed AL amyloidosis: a multicenter phase 1/2 dose-escalation study. Blood 2010, 116:4777-4782

64. Kastritis E, Wechalekar AD, Dimopoulos MA, Merlini G, Hawkins PN, Perfetti V, Gillmore JD, Palladini G: Bortezomib with or without dexamethasone in primary systemic (light chain) amyloidosis. J Clin Oncol 2010, 28:1031-1037.

65. Reece DE, Sanchorawala V, Hegenbart U, Merlini G, Palladini G, Bladé J, Fermand JP, Hassoun H, Heffner L, Vescio RA, Liu K, Enny C, Esseltine DL, van de Velde H, Cakana A, Comenzo RL: Weekly and twice-weekly bortezomib in patients with systemic AL amyloidosis: results of a phase 1 dose-escalation study. Blood 2009, 114:1489-1497.

66. Mikhael JR, Schuster SR, Jimenez-Zepeda VH, Bello N, Spong J, Reeder CB, Stewart AK, Bergsagel PL, Fonseca R: Cyclophosphamide-bortezomibdexamethasone (CYBORD) produces rapid and complete hematological response in patients with AL amyloidosis. Blood 2012, 119:4398-4389.

67. Venner CP, Lane T, Foard D, Rannigan L, Gibbs SD, Pinney JH, Whelan CJ Lachmann HJ, Gillmore JD, Hawkins PN, Wechalekar AD: Cyclophosphamide, bortezomib and dexamethasone therapy in $\mathrm{AL}$ amyloidosis is associated with high clonal response rates and prolonged progression free survival. Blood 2012, 119:4387-Inday.

68. Comenzo RL, Vosburgh E, Simms RW, Bergethon P, Sarnacki D, Finn K, Dubrey S, Faller DV, Wright DG, Falk RH, Skinner M: Dose-intensive melphalan with blood stem cell support for the treatment of $\mathrm{AL}$ amyloidosis: one-year follow-up in five patients. Blood 1996, 88:2801-2806

69. Comenzo RL, Vosburgh E, Falk RH, Sanchorawala V, Reisinger J, Dubrey S, Dember LM, Berk JL, Akpek G, LaValley M, O'hara C, Arkin CF, Wright DG, Skinner M: Dose-intensive melphalan with blood stem-cell support for the treatment of $\mathrm{AL}$ (amyloid light-chain) amyloidosis: survival and responses in 25 patients. Blood 1998, 91:3662-3670.

70. Landau H, Hassoun H, Bello C, Hoover E, Riedel ER, Nimer SD, Comenzo RL: Consolidation with bortezomib and dexamethasone following riskadapted melphalan and stem cell transplant in systemic AL amyloidosis. Amyloid. 2011, 18(Suppl 1):130-131.

71. Dispenzieri A, Lacy MQ, Kyle RA, Therneau TM, Larson DR, Rajkumar SV, Fonseca R, Greipp PR, Witzig TE, Lust JA, Gertz MA: Eligibility for hematopoietic stem-cell transplantation for primary systemic amyloidosis is a favorable prognostic factor for survival. J Clin Oncol 2001, 19:3350-3356

72. Lebovic D, Hoffman J, Levine BM, Hassoun H, Landau H, Goldsmith $Y$, Maurer MS, Steingart RM, Cohen AD, Comenzo RL: Predictors of survival in patients with systemic light-chain amyloidosis and cardiac involvement initially ineligible for stem cell transplantation and treated with oral melphalan and dexamethasone. Br J Haematol 2008, 143:369-373.

73. Gertz MA, Lacy MQ, Lust JA, Greipp PR, Witzig TE, Kyle RA: Long-term risk of myelodysplasia in melphalan-treated patients with immunoglobulin light-chain amyloidosis. Haematologica 2008, 93:1402-1406.

74. Gertz MA, Hayman SR, Buadi FK: Transplantation for IgM amyloidosis and IgM myeloma. Clin Lymphoma Myeloma 2009, 9:77-79.

75. Sanchorawala V, Wright DG, Rosenzweig M, Finn KT, Fennessey S, Zeldis JB, Skinner M, Seldin DC: Lenalidomide and dexamethasone in the treatment of AL amyloidosis: results of a phase 2 trial. Blood 2007, 109:492-496.

76. Dispenzieri A, Lacy MQ, Zeldenrust SR, Hayman SR, Kumar SK, Geyer SM, Lust JA, Allred JB, Witzig TE, Rajkumar SV, Greipp PR, Russell SJ, Kabat B, Gertz MA: The activity of lenalidomide with or without dexamethasone in patients with primary systemic amyloidosis. Blood 2007, 109:465-470.

77. Kastritis E, Anagnostopoulos A, Roussou M, Toumanidis S, Pamboukas C, Migkou M, Tassidou A, Xilouri I, Delibasi S, Psimenou E, Mellou S, Terpos E, Nanas J, Dimopoulos MA: Treatment of light chain (AL) amyloidosis with the combination of bortezomib and dexamethasone. Haematologica 2007, 92:1351-1358.
78. Wechalekar AD, Lachmann HJ, Offer M, Hawkins PN, Gillmore JD: Efficacy of bortezomib in systemic $\mathrm{AL}$ amyloidosis with relapsed/refractory clonal disease. Haematologica 2008, 93:295-298.

79. Lamm W, Willenbacher W, Lang A, Zojer N, Müldür E, Ludwig H, SchauerStalzer B, Zielinski CC, Drach J: Efficacy of the combination of bortezomib and dexamethasone in systemic AL amyloidosis. Ann Hematol 2011, 90:201-206

80. Zonder JA SV, Snyder RM, Matous J, Terebelo H, Janakiraman N, Mapara MY, Lalo S, Tageja N, Webb C, Monsma D, Sellers C, Abrams J, Gasparetto C: Melphalan and dexamethasone plus bortezomib induces hematologic and organ responses in AL-amyloidosis with tolerable neurotoxicity. Blood (ASH Annual Meeting Abstracts) 2009, 114:746.

81. Tirzaman O, Wahner-Roedler DL, Malek RS, Sebo TJ, Li CY, Kyle RA: Primary localized amyloidosis of the urinary bladder: a case series of 31 patients. Mayo Clin Proc 2000, 75:1264-1268.

82. Sattianayagam PT, Gibbs SD, Pinney JH, Wechalekar AD, Lachmann HJ, Whelan CJ, Gilbertson JA, Hawkins PN, Gillmore JD: Solid organ transplantation in AL amyloidosis. Am J Transplant 2010, 10:2124-2131.

83. Mignot A, Varnous $S$, Redonnet M, Mignot A, Varnous $S$, Redonnet $M$, Jaccard A, Epailly E, Vermes E, Boissonnat P, Gandjbakhch I, Herpin D, Touchard G, Bridoux F: Heart transplantation in systemic (AL) amyloidosis: a retrospective study of eight French patients. Arch Cardiovasc Dis 2008, 101:523-532.

84. Herrmann SM, Gertz MA, Stegall MD, Dispenzieri A, Cosio FC, Kumar S, Lacy MQ, Dean PG, Prieto M, Zeldenrust SR, Buadi FK, Russell SJ, Nyberg SL, Hayman SR, Dingli D, Fervenza FC, Leung N: Long-term outcomes of patients with light chain amyloidosis $(\mathrm{AL})$ after renal transplantation with or without stem cell transplantation. Nephrol Dial Transplant 2011, 26:2032-2036

85. Bridoux F, Ronco P, Gillmore J, Fermand JP: Renal transplantation in light chain amyloidosis: coming out of the cupboard. Nephrol Dial Transplant 2011, 26:1766-1768.

86. Guidelines Working Group of UK Myeloma Forum: British Commitee for Standards in Haematology, British Society for Haematology: Guidelines on the diagnosis and management of $\mathrm{AL}$ amyloidosis. $\mathrm{Br} J$ Haematol 2004, 125:681-700.

87. Pardanani A, Witzig TE, Schroeder G, McElroy EA, Fonseca R, Dispenzieri A, Lacy MQ, Lust JA, Kyle RA, Greipp PR, Gertz MA, Rajkumar SV: Circulating peripheral blood plasma cells as a prognostic indicator in patients with primary systemic amyloidosis. Blood 2003, 101:827-830.

88. Hasserjian RP, Goodman HJB, Lachmann HJ, Muzikansky A, Hawkins PN: Bone marrow findings correlate with clinical outcome in systemic AL amyloidosis. Histopathology 2007, 50:567-573.

89. Pepys MB, Herbert J, Hutchinson WL, Tennent GA, Lachmann HJ, Gallimore JR, Lovat LB, Bartfai T, Alanine A, Hertel C, Hoffmann T, Jakob-Roetne R, Norcross RD, Kemp JA, Yamamura K, Suzuki M, Taylor GW, Murray S, Thompson D, Purvis A, Kolstoe S, Wood SP, Hawkins PN: Targeted pharmacological depletion of serum amyloid $\mathrm{P}$ component for treatment of human amyloidosis. Nature 2002, 417:254-259.

90. Bodin K, Ellmerich S, Kahan MC, Tennent GA, Loesch A, Gilbertson JA, Hutchinson WL, Mangione PP, Gallimore JR, Millar DJ, Minogue S, Dhillon AP, Taylor GW, Bradwell AR, Petrie A, Gillmore JD, Bellotti V, Botto M, Hawkins PN, Pepys MB: Antibodies to human serum amyloid P component eliminate visceral amyloid deposits. Nature 2010, 468:93-97.

doi:10.1186/1750-1172-7-54

Cite this article as: Desport et al: AL Amyloidosis. Orphanet Journal of Rare Diseases 2012 7:54. 